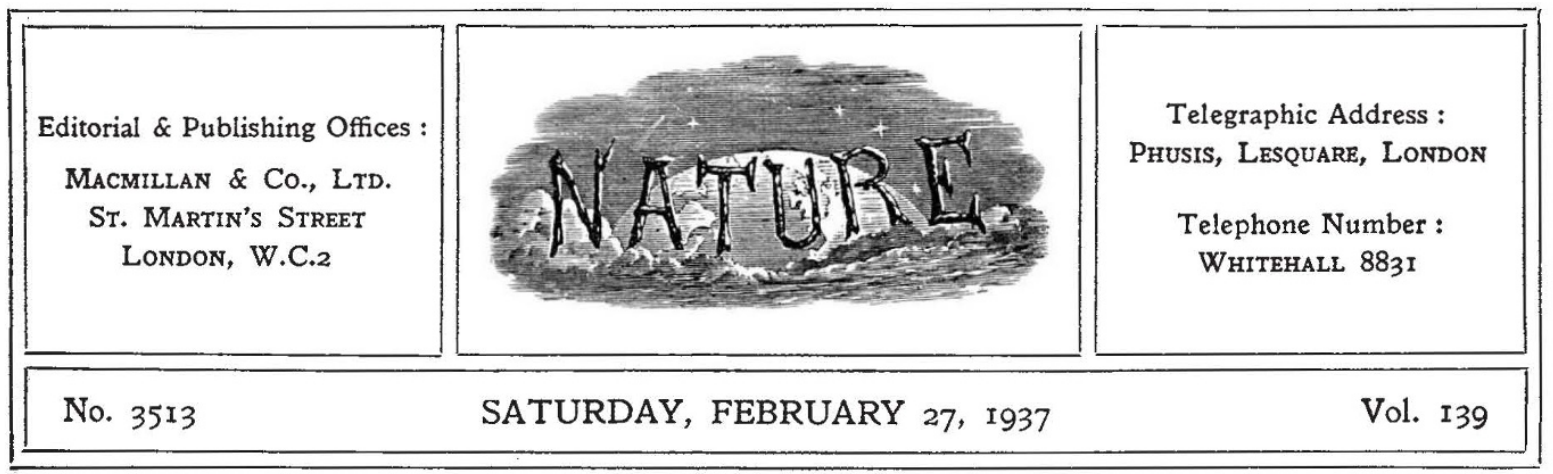

\title{
Conservation of Buildings and Landscape
}

$\mathrm{T}$ HE discussion which took place in the House of Commons on February 10 on the motion of Mr. A. C. Bossom, member for Maidstone, on the destruction of beauty in town and country and of buildings of historical or architectural interest now proceeding in Britain, evoked a striking unanimity in expression of opinion from all sides. The motion had not only called upon the House to deplore the present situation and to agree as to its urgency; but it had also pressed upon the Government the need for active steps to ascertain "whether its existing powers are adequate, or whether they require substantial reinforcement". No voice was raised to repudiate responsibility, or to deny that this destruction was in the least degree anything ${ }^{*}$ but a serious matter of public concern; while in the final result the motion was adopted by the Government, and an inquiry promised.

In the course of the debate, it became evident that there was a general consensus of opinion that control of development, in so far as it affects the beauty of rural Britain, the preservation of structures of historic interest in a broad sense, and the protection of buildings and landscape from grossly incongruous structural associations, is in present conditions a national duty and not merely a matter of a local sense of responsibility. This also was the view, it may be mentioned incidentally, strongly urged by Sir Halford Mackinder and Sir Percy Hurd before the Council for the Preservation of Rural England on the following day.

While the House of Commons paid well-deserved tribute to the success of the Office of Works in carrying out its duties in the protection of ancient and historic monuments with the exiguous resources at its disposal, it was pointed out in debate that in the most extensive field of its operations, that of the inhabited house, its powers are restricted, and that here even more than elsewhere, its activities are impaired by lack of funds.

The inhabited house has always presented a difficult problem in this connexion. To a certain extent, no doubt, shortcomings in the action now open to public authority will be met by the legislation to be introduced on behalf of the National Trust, to which reference was made in the reply for the Government by Mr. R. S. Hudson, Parliamentary Secretary of the Ministry of Health, accompanied by an assurance of the good will and sympathy of the Ministry of Health, the Office of Works and the Treasury. The scheme, however, for which powers will be sought, as it is understood, will apply in the main to the larger and more important examples of domestic architecture, and will be of little avail for structures of lesser pretensions and the villages typical of rural Britain in its varied cultural phases, for which Mr. Marshall, member for Sheffield, stressed the importance of preservation, as a unitary whole, as examples of "an architecture wedded to the landscape in which it is situated", each of a type and characteristics peculiar to its environment.

The problem of preserving these humbler structures should not be insuperable. Recent experience in reconditioning has shown how far villages, in which buildings have already been or are about to be condemned, may be preserved at a reasonable charge, and that whole villages need not necessarily be radically changed in character or ruthlessly spoiled on a demand for sanitary reform, which is blind to all considerations but one, important as that may be. The ways of the county surveyor and the rural district council, 
however familiar, never cease to seem wonderful. Even in urban conditions where the call for improvement may be more insistent and financial considerations more difficult to meet, it may yet be possible to preserve historical and cultural associations, other things being equal, by the application of modern methods of reconditioning.

Of the two factors, lack of interest or knowledge and finance, which enter into the problem and appeared to weigh most with members of the House as insistently demanding the intervention of central authority, the latter, finance, demands by far the more drastic treatment. As Mr. Hudson pointed out in his reply, and as was mentioned by other speakers, training and knowledge are, or can be made, readily available for the advice of local authorities. Yet while it is true that there are numerous local societies-field clubs, natural history societies and archæological societies-distributed up and down the country, of which the members are fully competent, as the Parliamentary Secretary suggested, to educate their neighbours, anyone who is acquainted with actual conditions is well aware that the standing of these societies and the influence which they can bring to bear when action is contemplated in any given instance, varies enormously from one locality to another. The expression of instructed opinion available in these bodies needs to be co-ordinated and disseminated in such a manner that its weight will receive due recognition. For such an organized expression of opinion the machinery already exists in the various associations and federations in which these societies combine for the discussion of common interests. In certain directions and on occasion, common action is taken, at times with conspicuous success. More systematic organization with the specific needs of the present situation in view is required.

Further, would it be too much to ask, failing a systematic survey and enumeration of ancient and historic structures worthy of preservation, such as has been carried out by the Surrey County Council, and is, it is stated, to be urged on other authorities, that each town-planning scheme should include a clause safe-guarding such structures? Such a clause would show that an authoritative opinion had been obtained that no building of historic or æsthetic interest and importance had been marked for demolition, or, if any such there were, a reasoned justification for its destruction would be put forward for consideration and decision by central authority.
It is questionable if even this goes far enough. Excellent though the work of the Council for the Preservation of Rural England and similar organizations may be in creating a public sense of responsibility, no unofficial body, can view conditions so comprehensively, or speak with the authority of a central body or department, with powers delegated from the people as a whole.

Finance is obviously the real crux of the problem. Upon whom is the expense of conservation to fall ? Even under existing legislation, the powers of a local authority are considerable, though, it may seem unfortunately, permissive only. The town-planning acts make it possible for the authority to intervene-but do not require that it must intervene-when the demolition of a structure of historic interest is contemplated. At once there arises the question of compensation, with all the possibilities of abuse. Nor is it practical to expect that an authority with only a low rateable value upon which to draw, will contem. plate action entailing heavy expenditure, whether for purchase or compensation, with an entirely open mind. At the same time, to brand indiscriminately development of land or an urban site as merely personal greed, because such development conflicts with æsthetic ideals or archæological and historical interest, is to invite derision from those whose co-operation it is desirable to enlist.

Each instance must be judged on its own merits; and the arguments which weigh for conservation should help to determine where the financial burden should fall. When national considerations determine the issue - and this must cover the claims of associations bound up with the nation's history at large-or matters of wide general interest in the scientific pursuit of archæological and historical studies, as in the instances of the Roman Wall and the country around Stonehenge and Avebury, the burden of conservation is one which should fall on the nation's purse. A scale of grants might well be devised for the assistance of local funds, when interests more restricted in range, but nevertheless of historic, scientific or æsthetic weight, are involved and public action is demanded. On the broad issue, however, the principle should stand. As Sir Halford Mackinder said on the occasion to which reference has already been made, we and the countryside have grown together ; the loss of its beauty would be the loss of half of ourselves; and its protection should be a national charge. 